\title{
PENGEMBANGAN BAHAN AJAR UNTUK MAHÂRATUL ISTIMA'
}

\author{
Nurul Zuhriyah \\ (zuhriyahhnurul@gmail.com)
}

\section{(Dosen Fakultas Tarbiyah IAI Muhammadiyah Bima)} \begin{abstract}
الملخصص
مهارة الاستماع هي القدرة الأولى التي لابد أن تملكه كل الطلبة عند تعلم اللعة العربية. وفي الحقيقة هذه المهارة تربد أكثر إهتماما، لأنه المهارة الأساسية والمهيمة، بأنه إذا كانت لا يقدر على هذه المهارة جيدة ولن يستطيع أن يستمر تعلمههم إلى المهارات

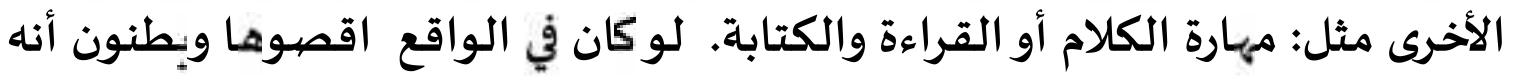

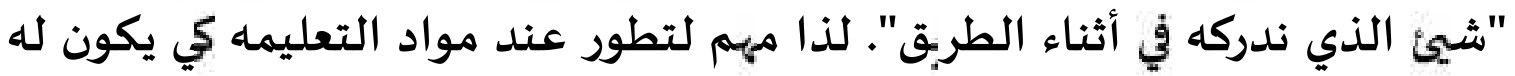
تركيزا وفعالا. هذه الكتابة ستهدف لكم إلى بيان وتصهور الأمثلة والأنطمة المهتمة عند كعل وتصيميم المواد التعليمية لمهارة الاستماع
\end{abstract}

Maharatul istima' (keterampilan menyimak) adalah kemampuan awal yang harus benarbenar dikuasai oleh pembelajar bahasa arab sebelum menguasai keterampilanketerampilan lainya seperti Mahâratul Kalâm (keterampilan berbicara), Mahâratul Qira'ah (keterampilan membaca), dan Mahâratul Kitâbah (keterampilan menulis). Tetapi fakta yang terjadi adalah, pembelajaran menyimak hingga sekarang agak diabaikan dan terkesan diremehkan serta belum mendapatkan tempat yang sewajarnya dengan porsi yang paling sedikit dalam pembelajaran bahasa Arab. Sehingga pembelajaran istima' dianggap pembelajaran 'sambil jalan juga akan bisa'. Istima' merupakan salah satu keterampilan reseptif yang menjadi unsur yang harus lebih dahulu dikuasai oleh siswa, maka jika keterampilan ini tidak dikuasai dengan baik maka akan sangat mempengaruhi penguasaan keterampilan lainya. Oleh sebab itu dibutuhkan beberapa pengembangan terhadap bahan ajarnya agar dapat lebih terfokus dan maksimal. Maka tulisan ini akan memberikan gambaran tentang beberapa contoh dan hal hal yang perlu diperhatikan ketika membuat atau mendesain bahan ajar maharatul istima'.

\section{Kata Kunci: Pengembangan, Bahan Ajar, Mahâratul Istima'}




\section{A. Pendahuluan}

Para ahli menyimpulkan bahwa menyimak adalah dasar dari keterampilan lainya, bahkan juga ada yang berpendapat bahwa waktu yang dipergunakan atau yang dihabiskan dalam berkomunikasi sehari hari dapat dibagi sebagai berikut, $25 \%$ untuk menyimak, $15 \%$ untuk berbicara, $15 \%$ untuk membaca dan $10 \%$ untuk menulis. Sehingga proporsi waktu yang digunakan untuk kegiatan menyimak lebih banyak apabila dibandingkan dengan proporsi waktu yang digunakan untuk kegiatan lainya. Ini berarti dalam kehidupan sehari-hari manusia tidak bisa lepas dari kesibukannya yang menuntut keterampilan menyimak. Misalnya bercakap-cakap dengan teman, berdiskusi di kelas dan mendengarkan televisi menuntut keterampilan menyimak. Sehingga keterampilan menyimak adalah salah satu kemahiran berbahasa yang sangat penting dan perlu dikuasai oleh para siswa. Para linguistik menyatakan bahwa bahasa itu pertama-tama adalah ujaran, yakni bunyi-bunyi bahasa yang diucapkan dan bisa didengarkan. Dengan demikian menyimak merupakan satu pengalaman belajar yang harus mendapatkan perhartian yang sungguh-sungguh dari pengajar. ${ }^{1} \mathrm{Hal}$ tersebut dikuatkan oleh Rusydi Ahmad Thuaimah bahwa seseorang yang memiliki kemampuan mendengar yang baik pasti ditunjang dengan kemampuan kemampuan seperti: memiliki pengetahuan bahasa Arab yang baik, jelas arah dan tujuan apa yang dibicarakan, memiliki pengetahuan tentang bentuk-bentuk budaya yang berkaitan dengan bahasa Arab. ${ }^{2}$

Dalam hal ini pengajar harus memiliki inisiatif dan kreatifitas untuk membuat pembelajaran (maharatul istima') lebih menarik lagi. Dan salah satu cara yang bisa dilakukan adalah mengembangkan bahan ajarnya agar lebih mampu memberikan efektifitas bagi pelajar dan tentunya memudahkan pengajar itu sendiri. Karena selama ini khususnya untuk maharatul istima' belum terlalu banyak dilakukan penambahan bahan ajar ataupun renovasi untuk membuatnya lebih menarik. Kalaupun ada maka bahan-bahan ajar bahasa Arab yang berkembang dan banyak digunakan di Indonesia pada umumnya adalah bahan ajar yang biasa digunakan oleh madrasah-madrasah di

\footnotetext{
${ }^{1}$ Syaiful Mustofa, Strategi Pembelajaran Bahasa Arab, (Malang : UIN Maliki Malang, 2017), 113-114.

${ }^{2}$ Qomi Akid Jauhari, Pembelajaran Maharah Istima' di Jurusan PBA UIN Maulana Malik Ibrahim Malang, Jurnal Tarbiyatuna, Vol.3, No.1, Januari-Juni 2018, 130.
} 
Timur Tengah atau Barat. Kalaupun bahan ajar tersebut adalah hasil pengembangan, maka jumlahnya tidaklah begitu banyak. Sementara tuntutan masyarakat akademik mengenai perlunya inovasi dan pengembangan bahan ajar bahasa Arab dewasa ini terus bergulir, seiring dengan dinamika perkembangan ilmu pengetahuan dan teknologi. Selain itu, tuntutan adanya bahan ajar Arab yang menggunakan bahasa Indonesia sebagai bahasa pengantarnya berkembang disebagian peserta didik. Sehingga Salah satu kompetensi yang perlu dimiliki seorang guru dalam melaksanakan tugasnya adalah mengembangkan bahan ajar. Pengembangan bahan ajar penting dilakukan guru agar pembelajaran lebih efektif, efisien dan tidak melenceng dari kompetensi yang ingin dicapai. Kompetensi mengembangkan bahan ajar idealnya telah dikuasai guru secara baik, namun pada kenyataannya masih banyak guru yang belum menguasainya, sehingga dalam melakukan proses pembelajaran masih banyak yang bersifat konvensional. Dampak dari pembelajaran konvensional ini antara lain aktivitas guru lebih dominan dan siswa kurang aktif. Di samping itu, pembelajaran yang dilakukannya tentu kurang menarik karena pembelajaran kurang variatif. ${ }^{3}$ Untuk itu, perlu sebuah pengkajian yang lebih mendalam dan perhatian serta keseriusan dalam mengembangkan bahan ajar yang dimaksud agar hasil yang ingin dicapai bisa maksimal dan sesuai dengan harapan, karena hal yang menjadi bahan pengkajian memang khusus terfokus pada maharatul istima'.

\section{B. PEMBAHASAN}

\section{Bahan Ajar}

\section{a. Pengertian Bahan Ajar}

Bahan ajar dapat diartikan bahan-bahan atau materi pelajaran yang disusun secara lengkap dan sistematis berdasarkan prinsip-prinsip pembelajaran yang digunakan guru dan siswa dalam proses pembelajaran. Bahan ajar bersifat sistematis artinya disusun secara urut sehingga memudahkan siswa belajar. Di samping itu, bahan ajar juga bersifat unik dan spesifik. Unik maksudnya bahan ajar hanya digunakan untuk sasaran tertentu dan dalam proses pembelajaran

\footnotetext{
${ }^{3}$ Khairi Abu Syairi, Pengembangan Bahan Ajar Bahasa Arab, Dinamika Ilmu, Vol. 13. No. 1,
} Juni 2013, 51. 
tertentu, dan spesifik artinya isi bahan ajar dirancang sedemikian rupa hanya untuk mencapai kompetensi tertentu dari sasaran tertentu. Dalam kegiatan pembelajaran, bahan ajar sangat penting artinya bagi guru dan siswa. Guru akan mengalami kesulitan dalam meningkatkan efektifitas pembelajarannya jika tanpa disertai bahan ajar yang lengkap. Begitu pula bagi siswa, tanpa adanya bahan ajar, siswa akan mengalami kesulitan dalam belajarnya. Hal tersebut diperparah lagi, jika guru dalam menjelaskan materi pembelajarannya cepat dan kurang jelas. Oleh karena, itu bahan ajar merupakan hal yang sangat penting untuk dikembangkan sebagai upaya meningkatkan kualitas pembelajaran. Sebagaimana yang diketahui, pembelajaran mencakup empat komponen, yaitu: pembelajar, media, sumber, dan pengajar. Bahan ajar merupakan media dan sumber belajar yang memiliki kedudukan yang strategis. ${ }^{4}$

\section{b. Strategi Pemilihan dan Penyusunan Pengembangan Bahan Ajar untuk Maharatul Istima'}

Strategi pemilihan bahan ajar bahasa Arab untuk mencapai pembelajaran mahatul istima' yang efektif dan efisien serta sampai pada tujuan, pengembangan atau revisi secara berkala tentu menjadi hal yang sangat penting. Dick dan Carey mengemukakan ada dua pengembangan atau revisi yang perlu dipertimbangkan untuk mencapai hal di atas, yaitu: a). Revisi terhadap isi atau subtansi bahan pembelajaran maharatul istima' agar lebih cermat dan fokus b). Revisi terhadap cara-cara yang dipakai dalam menggunakan bahan pembelajaran ${ }^{5}$ untuk maharatul istima'.

Adapun hal-hal yang bisa dilakukan oleh pengajar itu sendiri untuk mencapai dua hal diatas adalah:

\section{Mempersiapkan Modul}

Tentunya modul tersebut mampu memberikan detail materi yang dipelajari untuk latihan peningkatan kemampuan mendengar bagi para siswa. Baik itu ketika mereka berada didalam kelas, rumah maupun dimanapun. Tentunya materi-materi yang ada didalam modul tetap

${ }^{4}$ ibid., 53.

5 ibid., 58. 
terfokus pada maharatul istima' dan pengembangan dari materi berasal tersebut bisa berasal dari dalam buku paket pembelajaran bahasa Arab siswa, buku latihan maupun sumber-sumber lainnya. Menurut Goldschmid, modul pembelajaran sebagai satuan kegiatan belajar yang terencana, didesain guna membantu siswa menyelesaikan tujuan-tujuan tertentu. Modul adalah semacam paket program untuk keperluan belajar. ${ }^{6}$ Modul minimal memuat tujuan pembelajaran, materi atau subtansi belajar dan evaluasi. Modul juga berfungsi sebagai sarana belajar yang bersifat mandiri, sehingga peserta didik dapat belajar secara mandiri sesuai dengan kecepatan masing - masing.

\section{Praktek Membuat Audio dan Video}

Perkembangan teknologi yang semakin pesat harus bisa dimanfaatkan dengan sebaik mungkin oleh para pengajar bahasa Arab, jika biasanya audio atau video didapatkan dari rekaman kaset atau video lama yang telah berisi rekaman suara orang Arab, maka sebaiknya guru juga memberikan kesempatan kepada siswa untuk mengekplorasi kemampuannya dalam mengolah media-media tersebut. Kemudian, hasil dari pada praktik membuat video atau merekam suara mereka dalam audio dapat diperdengarkan dilaboraturium atau dengan speaker didalam kelas bersama siswa lainya.

\section{c. Langkah Penyusunan Bahan Ajar untuk Maharatul Istima'}

Adapun langkah-langkah pengembangan dalam penyususnan bahan ajar (maharatul istima'), secara rinci Hamid dkk, menjelaskan prosedur pengembangan bahan ajar bahasa Arab seperti berikut ini:

\section{a) Analisis}

Yang dilakukan adalah mengumpulkan informasi berkaitan dengan pelajaran bahasa Arab dalam aspek maharatul istima' dimulai dari silabusnya, juga mengumpulkan informasi tentang karakteristik awal siswa. Sebelum memulai proses pengembangan, tahap pertama yang

${ }^{6}$ Cece Wijaya, Upaya Pembaruan dalam Pendidikan dan Pengajaran, (Bandung: Remadja Karya, 1988), 20. 
dilakukan adalah menentukan materi apa yang akan dikembangkan. Setelah ditetapkan, langkah selanjutnya adalah menganalisis silabus untuk diidentifikasi pokok-pokok bahasannya, dan mengenali karakteristik siswa sebagai pengguna bahan ajar bahasa Arab yang akan dikembangkan. Mengidentifikasi tingkah laku dan karakteristik siswa merupakan hal yang sangat penting untuk dipertimbangkan dalam rangka merancang kegiatan-kegiatan pembelajaran. Beberapa hal yang perlu diidentifikasi, khususnya yang berkaitan dengan siswa sebagai pengguna buku bahan ajar bahasa Arab adalah: 1) Kondisi dimana sumber belajar berupa buku ajar diterapkan, 2) Siapa yang menggunakan buku ajar, dan 3) Untuk kelas atau tingkat berapa buku ajar itu digunakan.

\section{b) Perancangan}

Pada tahap ini, langkah-langkah yang harus ditempuh adalah: 1) Menganalisis dan merumuskan tujuan pembelajaran dengan melibatkan empat unsur, yaitu: A= Audience, artinya siapa yang akan belajar. $\mathrm{B}=$ Behavior, artinya perilaku khusus yang akan dimunculkan oleh siswa setelah selesai proses belajar mengajar. $\mathrm{C}=$ Condition, artinya keadaan yang harus dipenuhi pada saat proses belajar-mengajar berlangsung serta keadaan ataupun alat yang digunakan siswa pada saat ia di tes, bukan pada saat ia belajar. $\mathrm{D}=$ Degree, artinya tingkat keberhasilan yang harus dipenuhi oleh siswa.

\section{c) Mengembangkan Butir-Butir Tes}

Penyusunan butir-butir tes perlu memperhatikan hal-hal sebagai berikut: a) Berdasarkan kriteria yang dirumuskan dalam tujuan khusus pembelajaran istima', b) Berdasarkan muatan materi pada pokok bahasan yang akan dikembangkan dalam penyusunan pertanyaan, c) Memperhatikan kesesuaian butir soal dengan tujuan khusus pembelajaran atau indikator keberhasilan, d) Membuat bentuk-bentuk soal dan menyusunnya e) Menulis petunjuk, dan f) Mengerjakan soal- 
soal yang menghasilkan kunci jawaban. Hasil akhir dari langkah ini adalah seperangkat soal-soal latihan dan soal-soal tes yang dapat digunakan untuk mengukur penguasaan siswa terhadap materi yang sudah dipelajarinya. Di dalam pembelajaran selanjutnya butir-butir soal ini akan dikembangkan menjadi soal-soal latihan, tugas-tugas, soal-soal tes sumatif atau formatif

\section{d) Mengembangkan Strategi Pembelajaran}

Dalam strategi pembelajaran khusunya, terdapat lima komponen utama yang akan menjadi fokus, yaitu: 1) Kegiatan pembelajaran, 2) penyajian atau penyampaian informasi, 3) peran serta siswa, 4) pengetesan, dan 5) tindak lanjut. Untuk meningkatkan efektivitas penggunaannya, buku ajar disusun dengan dilengkapi beberapa komponen pendukung pembelajaran, yaitu: 1) petunjuk cara mempelajari uraian pada setiap isi topik, 2) tujuan pembelajaran setiap topik dan sub topik, 3) daftar bacaan yang relevan, dan 4) soal-soal latihan. 4) Mengembangkan media pembelajaran dan sumber belajar, menurut Belawati adalah alat dan cara untuk memfasilitasi, mempermudah proses belajar siswa, serta membuat proses belajar menjadi lebih menyenangkan dan menarik bagi siswa. Media dan sumber belajar yang dapat dipilih untuk paket bahan ajar pembelajaran bahasa Arab dalam aspek maharatul istima' antara lain: modul, poster, video, dan lain-lain.

\section{e) Mengembangkan Materi Pembelajaran}

Materi pembelajaran dikembangkan dengan beberapa langkah sebagai berikut: a) Memilih dan mengumpulkan materi pembelajaran yang ada dan relevan untuk digunakan, b) Menyusun materi sesuai dengan urutan kegiatan pembelajaran, c) Mengidentifikasi materimateri yang diperoleh dan yang tidak diperoleh dari buku, dan d) Menyusun program pengajaran sebagai langkah awal dalam mengembangkan materi adalah memilih dan menentukan topik dan 
judul, langkah pemilihan topik mata pelajaran mengacu pada kurikulum dan analisis instruksional, kemudian membuat peta konsep yang akan menjadi landasan ruang lingkup uraian topik mata pelajaran dalam bahan ajar bahasa Arab.

\section{f) Penulisan dan Penyusunan Materi}

Penyusunan, pemilihan dan penulisan bahan pembelajaran berupa buku ajar meliputi: 1) Menyusun dan menulis petunjuk 2) Menyusun dan menulis tujuan pembelajaran 3) Menyusun dan menulis uraian materi pelajaran 4) Menyusun dan menulis soal-soal, latihan-latihan, tes dan kunci jawaban 5) Menyusun dan menulis daftar mufrodat.

\section{g) Evaluasi}

Pada tahap ini buku yang telah disusun kemudian dievalusi kembali. Evaluasi ini dilakukan untuk mengumpulkan data yang digunakan dalam penyempurnaan buku ajar. Untuk evaluasi bahan ajar bahasa Arab dapat dilakukan 3 langkah kajian, yaitu: 1) evaluasi tahap pertama, berupa review atau kajian oleh bidang studi, dan ahli rancangan pembelajaran 2) tahap kedua, uji coba perorangan dan 3) tahap tiga, uji coba lapangan. ${ }^{7}$

\section{Mahâratul Istima'}

Para ahli lingustik membedakan antara mendengar (as-simā'), menyimak (alistimā), dan mendengar dengan serius (alin āt). Mendengar (as-simā') hanyalah menerima suara yang tanpa adanya perhatian dan unsur kesengajaan, seperti suara bising atau hiruk pikuk di jalan raya. Sedangkan menyimak (al-istimā') adalah menuntut adanya kesengajaan dan perhatian dalam mendengarkan segala sesuatu, dan mendengar dengan serius (al-in $\bar{a} t$ ) adalah tingkatan lebih di atas menyimak yang menuntut konsentrasi dan perhatian yang lebih pada pembicaraan si penutur. ${ }^{8}$

\footnotetext{
${ }^{7}$ Ibid., 62-64

${ }^{8}$ Muhammad Ediyani; Abdul Munip, Pengembangan Materi Pembelajaran Mahārah Al Istimā' Berbasis Media Lectora Inspire Di Madrasah Aliyah Swasta Ulumuddin Lhokseumawe Aceh, At-Tajdid, Jurnal Ilmu Tarbiyah, Vol. 6, No. 2, Juli 2017, 203.
} 
Sebagai salah satu dari empat kemampuan berbahasa, mendengar merupakan keterampilan yang memungkinkan seorang pemakai bahasa untuk memahami bahasa yang digunakan secara lisan. Karena banyaknya komunikasi sehari-hari yang dilakukan secara lisan, kemampuan ini amat penting dimiliki oleh setiap pemakai bahasa. Tanpa kemampuan mendengar yang baik, akan terjadi banyak kesalahpahaman dalam komunikasi antara sesama pemakai bahasa yang dapat menyebabkan berbagai hambatan dalam melaksanakan tugas dan kehidupan seharihari. Oleh karena itu kemampuan mendengar merupakan bagian yang tidak boleh diabaikan dalam pengajaran bahasa terutama bila tujuan penyelenggaraannya adalah penguasaan kemampuan berbahasa. Dalam pengajaran bahasa semacam itu perkembangan dan tingkat penguasaan kemampuan mendengar perlu dipantau. Kemampuan mendengar terkait dengan kemampuan untuk memahami makna suatu bentuk penggunaan bahasa yang diungkapkan secara lisan. Kemampuan mendengar terkait dengan kemampuan untuk memahami makna suatu bentuk bahasa yang diungkapkan secara lisan ${ }^{9}$

\section{Pengertian Maharatul Istima'}

Menyimak (istima') adalah suatu proses yang meliputi kegiatan mendengarkan bunyi bahasa, mengidentifakasi, menafsirkan, dan mereaksi makna yang terkandung di dalamnya. Maharah istima' adalah kemampuan seseorang dalam menyerap atau memahami kata maupun kalimat yang diucapkan oleh lawan bicara atau media tertentu. ${ }^{10}$ Dikuatkan dalam pendapat lain bahwa maharatul Istima' (keterampilan menyimak) adalah kemampuan seseorang dalam mencerna dan memahami kata-kata atau kalimat yang diujarkan oleh mitra bicara atau media tertentu. Kemampuan ini sebenarnya dapat dicapai dengan latihan yang terus menerus untuk mendengarkan perbedaan bunyi, kata ataupun unsur-unsur lainya menurut makhraj huruf yang benar, baik langsung dari penutur aslinya maupun melalui rekaman. ${ }^{11}$ Istima'

\footnotetext{
${ }^{9}$ Erryk Kosbandhono : Esesmen Dan Evaluasi Untuk Maharah Istima', Arabia, Vol. 5, No. 1, Januari Juni 2013, 2-3.

${ }^{10}$ Nuril Mufidah, Irtahat Isyaty, Nur Kholis, dan Saidna Zulfiqar Bin Tahir, Ict For Arabic Learning: A Blended Learning In Istima' II, Lisanuna, Vol. 8, No. 2, 2018, 177.

${ }^{11}$ Acep Hermawan, Metodolgi Pembelajaran Bahasa Arab, (Bandung: Remaja Rosdakarya, 2014), 130
} 
yang dalam bahasa Inggris disebut listening, bukan sekedar sama' (hearing), akan tetapi al-inshat (auding). Dalam proses sama', orang mendengar hanya sekedar mendengar, tanpa adanya perhatian dan tujuan. Berbeda dengan alinshat (auding), dalam proses ini orang mendengar memang sengaja mendengarkan, sehingga disertai dengan perhatian dan adanya tujuan yang ingin dicapai dalam proses mendengarnya itu. Abdul Majid Sayyid Ahmad Mansur mendefenisikan " الاستماع هو عملية إنصات إلى الرموز المنطوقة ثم تفسيرها " Artinya: "Proses mendengarkan dengan serius (inshat) kode-kode bahasa yang diucapkan kemudian menafsirkannya."

Demikian juga dengan pembelajaran keterampilan menyimak. Tujuan utamanya adalah mengenal dengan baik aturan bunyi yang ada dalam bahasa Arab. Kemudian pada tingkat menengah dituntut untuk memahami perbedaan bunyi dan implikasinya terhadap makna.

\section{Urgensi Maharatul Istima'}

Dalam Pembelajaran Bahasa Arab setiap bahasa mempunyai aturan bunyi yang khas. Seorang anak ketika memahami aturan bunyi bahasa ibu, membutuhkan waktu kurang lebih lima tahun untuk menjadikannya pengetahuan permanen dalam otak ketika anak memasuki usia pasca lima tahun ini, dia akan menghadapi masalah yang sangat urgen dalam mempelajari bahasa asing disebabkan kepermanenan bahasa ibu di dalam otak. Persoalan yang umumnya dihadapi oleh orang yang belajar bahasa asing adalah mereproduksi bunyi yang tidak ditemukan dalam bahasa ibu. Sebagai contoh, orang Indonesia ketika belajar huruf Arab (huruf hijaiyah) akan lebih sulit mengucapkan huruf kha' dari pada huruf ba'. Hal ini disebabkan aturan bunyi huruf kha' tidak ditemukan sebelumnya dalam bahasa ibu. Berbeda huruf ba', aturan bunyi huruf ini telah temukan dalam bahasa ibu. ${ }^{12}$

\footnotetext{
${ }^{12}$ Muh. Nidom Hamami AC, Assesement dan Evaluasi Kemampuan Menyimak (Istima'), Pembelajaran Bahasa Arab, Jurnal “TURATS”, Vol. 5,No. 10, Desember 2013, 497-498.
} 


\section{Tujuan Pembelajaran Mahâratul Istima'}

Tujuan pembelajaran keterampilan yang ingin dicapai dalam pembelajaran keterampilan menyimak. Hamadah Ibrahim mengatakan bahwa ada sepuluh tujuan pembelajaran keterampilan menyimak, yaitu:

1) Membiasakan telinga dengan suara suara baru.

2) Membiasakan siswa untuk mengucapkan bahasa baru.

3) Memahami soal agar mampu menjawabnya.

4) Mampu menangkap pesan dan berinteraksi dengannya.

5) Mampu mendiskusikan dan menerapkan isi yang didengar.

Sementara itu Sholah Abdul Majid mengatakan bahwa ada empat tujuan dalam pembelajaran keteranpilan menyimak adalah:

1) Untuk mengulang secara langsung (teks yang diperdengarkan).

2) Untuk menghafal (teks yang diperdengarkan).

3) Untuk mengambil pokok pikiran (teks yang diperdengarkan).

4) Untuk memahami (teks yang diperdengarkan). ${ }^{13}$

\section{KESIMPULAN}

Jika ingin menjadikan pembelajaran bahasa menjadi pelajaran yang sangat menarik maka perhatikanlah bagaimana para guru mengajarkan siswanya untuk menyimak. Menyimak atau istima' merupakan kompetensi pertama yang harus bisa dijadikan pijakan utama, menjadi dasar kokoh dalam pembelajaran bahasa Arab. Oleh sebab itu perhatian kepadanya tidak boleh diabaikan begitu saja, atau dianggap remeh. Maka untuk mewujudkan hal tersebut diperlukan beberapa pengembangan terhadap bahan ajar, tentunya dengan syarat dan ketentuan serta prosedur yang telah ditetapkan. Jika pada beberapa tahun silam, penggunaan kaset dan vcd maka saat ini para guru bisa menggunakan fitur-fitur yang segar dan lebih dipahami oleh para siswa serta kekinian. Pengembangan bahan ajar mutlak harus dilakukan seiring dengan perkembangan kebutuhan para siswa. Karena hal tersebut akan memberikan guru kesempatan untuk menemukan cara-cara baru untuk bisa berinovasi dengan leluasa.

13 Ibid., 498 - 499. 


\section{DAFTAR PUSTAKA}

Abdul Munip dan Muhammad Ediyani. Pengembangan Materi Pembelajaran Mahārah Al Istimā' Berbasis Media Lectora Inspire Di Madrasah Aliyah Swasta Ulumuddin Lhokseumawe Aceh, At-Tajdid: Jurnal Ilmu Tarbiyah, Vol. 6 No. 2, Juli, 2017.

Acep Hermawan, Metodolgi Pembelajaran Bahasa Arab, Bandung: Remaja Rosdakarya. 2014.

Cece Wijaya, Upaya Pembaruan dalam Pendidikan dan Pengajaran, Remadja Karya, Bandung: Remaja Rosdakarya, 1988.

Syaiful Mustofa, Strategi Pembelajaran Bahasa Arab, Malang: UIN Maliki Malang, 2017.

Khairi Abu Syairi, Pengembangan Bahan Ajar Bahasa Arab, Dinamika Ilmu, Vol. 13. No. 1, Juni, 2013.

Qomi Akid Jauhari, Pembelajaran Maharah Istima' di Jurusan PBA UIN Maulana Malik Ibrahim Malang, Jurnal Tarbiyatuna, Vol. 3, No. 1, Januari-Juni, 2018.

Muh. Nidom Hamami, Assesement dan Evaluasi Kemampuan Menyimak (Istima') Dalam Pembelajaran Bahasa Arab, Jurnal “TURATS”, Vol.5, No.10 Desember, 2013.

Nuril Mufidah, dkk, Ict For Arabic Learning: A Blended Learning In Istima' II dalam Lisanuna, Vol. 8, No. 2. 2018.

Erryk Kosbandhono, Esesmen Dan Evaluasi Untuk Maharah Istima', Arabia, Vol. 5, No. 1, Januari - Juni, 2013. 